\title{
Discovery of The New World's Effects on European Economy Osman Sina YEKELER*
}

\begin{abstract}
European explorers and contemporary states have attempted to find new routes, regions due to various goals. They have explored the Americas, New World and have taken advantage of these explorations. Mines which provides direct wealth through usage of commodity money, have been extracted and transported, Americas' plants to the continental Europe which have led to growth in population and GDP have been transplanted to the Europe. It is argued that mines have been brought to the Europe, so accumulation of capital has occurred that leads to a massive influx of cash. Also, transplanted nutritive species have provided the population growth which has been effective on GDP increase with combining the accumulated money.
\end{abstract}

Keywords: Exploration of the New World, Americas' precious metals and plants, potato's effect on population, commodity money, influx of cash in Europe, accumulation of capital.

Jel Codes: N13, N16, N24, N26, N33, N36, N56, O13, O52, O54, B16

\section{Yeni Dünya'nın Keşfinin Avrupa Ekonomisine Etkisi}

\section{Özet}

Avrupalı kâşifler ve o zamanın Avrupa devletleri, çeşitli nedenlerden dolayı yeni ticari rotalar ve alanlar bulmaya çalıştı. Amerika kıtasını ve Yeni Dünya tabir edilen bölgeleri keşfederek bu keşiflerden birtakım faydalar elde ettiler. O tarihlerde mal para kullanıldığ için doğrudan zenginlik sağlayan madenler Avrupa'ya taşındığ olabileceğini düşündüğümüz Yeni Dünya'ya ait bitki türlerinin de Avrupa'ya nakli sağlandı. $\mathrm{Bu}$ madenlerin getirilmesi ile birlikte kıtaya akan parada devasa bir artış meydana geldi. Öte yandan, madenler dolayısıyla oluşan sermaye birikiminin bilhassa besleyici özelliği yüksek

\footnotetext{
"Researcher-Writer, Istanbul,Turkey, osmansina96@ hotmail.com
} 
olan bitkilerin transplantasyonu sayesinde artan nüfusu besleme potansiyeliyle birleşmesi Avrupa'nın gayri safi yurtiçi hasılası üzerinde etkili oldu.

Anahtar kelimeler: Yeni Dünya'nın keşfi, Amerika kıtasının değerli metalleri ve bitki türleri, patatesin nüfus üzerindeki etkisi, mal para, Avrupa'da para akışı, sermaye birikimi

Jel kodlar: N13, N16, N24, N26, N33, N36, N56, O13, O52, O54, B16

\section{Introduction}

Discovery of the New World mostly emphasizes the Americas' and the trans-Atlantic trade routes thanks to motives such as mercantile interests of the entrepreneurs and states, missionary activities and scientific curiosity. These acts have led to expansion of Europe's political and economic domain by using the precious metals, cheap labor and plantations of the New World in favor of the European states. Thus, precious metals have led to influx of bullion into Europe, cheap work force and agricultural changes began to make a profound effect upon the economy of the Old World so Europeans', discoverer of the New World, economy could not be stay as the same despite of new conditions so its discovery has become very effective on European economy's aggressive growth in time by taking the advantage of being pioneer of the discovery. Enriching silver and gold mines created an invasive money supply, purchasing power within the European continent and by way of a new route, trans-Atlantic, Europeans secured the new route for transportation of the enriching items to the their motherland without tariffs or attack of foreign countries, so it made the European economy more determinative in the world economy; also had the chance to exploit the local people, plantations in favor of their profit and to transplant new species to the motherland as in the example of potato, increased the population thanks to nutritiousness, boosted a wealthy European economy.

\section{Background}

We will be giving background information for clear understanding for New World's discovery and its so-called aims, mercantilism, colonization. Europeans' attempts or desire for discovering the New World was intentional or coincidental? Did they intentionally seek the New World to establish a new route? Actually, we cannot say that they have did these things 
or acted in this direction without a teleological approach. Parry has argued that Europeans were not generally seeking unknown lands, but were simply trying to link known markets by sea. Also, about the cause or aim of the discoveries, another scholar claims that Muslims were controlling the Mediterranean trade, so Europeans have been forced to seek new routes to control and make their trade. Lybyer was also claiming that "the advance of the Ottoman power gradually blocked the ancient trade-routes and forced a series of attempts to discover new routes". In the light of these arguments, we can assume that trading and economic controversies have led to discovery of the New World. Although, there are counter-arguments as Lane claims that European discoveries cannot happened because of blocking of the Mediterranean trade to explain the cause of the voyages of discovery. If Ottoman power blocked the traditional trade routes, prices should have risen in European relative to Asian markets because blockade of trade, but Lane finds no evidence that this in fact happened." Boxer mentions another point that emphasize the canonical character of the New World's discovery. Hence, it can be clearly stated that the discovery's intention was not because of mere unilateral conditions and complexity of the reasons seems much more reliable. In this direction, we can mention the Columbus' thoughts over the discovered places. He mentions Cuba “...has a great quantity of palms of a different sort from those of Guinea and our own unlike the rivers of Guinea, which are all pestilential". We state Columbus' letter because of possibility of clearer view for evaluation of that period's people. Thus, desire or eagerness to expand and exploitation is irrefutably clear even if there were canonical aims. Besides, mechanism of the colonization of the New World is another issue for understanding of the discoveries whether it was statebacked movement or entrepreneurs" movement or not. Lane asserts that "...in examining the organizations actually existing in the Western world about I900 it is not too difficult to classify them according to all three criteria either as governments or as business enterprises. But in examining the oceanic expansion of the fifteenth and sixteenth centuries, we cannot classify in this way the organizations initially involved". He also claims that feudalism was still dominant in Europe and even private properties could not have been mentioned at that time, so states' effect on voyages is clear. Herbert Lüthy also supports these arguments with his argument which asserts the diversity of the inputs in the New World's discovery and the colonization of the New World. There were adventurers, hundreds of thousands of colonists, elites and purely harsh imperialism of the Westerners to peaceful New World's countries cannot be discussed. These arguments show the mechanism of the discovery of the New World and how it is discovered, who became effective in these actions. Therefore, we cannot discuss only reason to understand the circumstances and also cannot evaluate discoveries and colonization with 
anachronic approaches that contain modern times' terms such as entrepreneurship or liberal economies. After that, this background information will be helpful to comprehend the contribution of the New World, we will be discussing in next chapter, to European prosperous economy. Before we pass to European economic development thanks to New World, it should be stated that increase of new trading networks and overseas activities were the basic cause of every matter we will be discussing, because all the contributions of New World will be basically happened thanks to overseas discoveries that created trans-Atlantic trading route.

\section{Findings}

First of all, flow of the precious metals from New World to Europe is prior cause for European economy's expansion through the mercantilism. We take the precious metals' usage in coining money at that time into consideration, because this issue will make our thesis, claiming these metals' positive effect on European economy's wealth was huge, more sensible. We put aside this and will be describing the economic growth of Europe thanks to precious metals through the example of Spain's mining of silver in Potosí. Spanish Crown has used their lands for silver mining with local work force and the silver was being brought from Potosí by Crown to their country through the ocean. Moreover, the Crown has had ownership of all mines and people only could be able to become leaseholder under the contract or be having working rights in Royal mines, so people in Royal-owned mines must have been paying taxes to the Crown. In accordance with Brading and Cross, the customary tax charged by the Crown for miners, refiners and merchants was fifth of the production and 1.5 percent of production was the assay cost in the beginning. The customary tax charged by the Crown, amounted to a fifth of production. When silver was cast in bar, the American miners were legally obliged to present it at the nearest treasury for stamping and payment of the fifth. In time, taxes were being decreased to 7 percent by the Crown because of reduction of the silver's production and even if discounts in taxes were made for only the miners in the beginning, later, all merchants, refiners have been included to the concession. This shows us the Royal mines in the New World must have been very profitable and beneficial for the Crown economy, because silver was being used as coin in trading at that time. Furthermore, another profitable source of Crown was selling of mercury which is indispensable for silver mining. Brading and Cross states that sizeable mercury deposits were in modern Slovenia, Peru and Spain which was the most dominant supplier in this field; were determining the prices of mercury, too. In addition to these economic advantages, the Crown could able to decree to enter all silver to mints for coinage, so by this way they can be determining the exchange ratio of silver to gold, too. Hence, on the basis of 
example of the Crown we can assert that the mining camps and towns that were established by Europeans in New World generated the precious metals to economic power for them such as purchasing power for buying items from all around the world and establishing new trading networks. Brading and Cross also states that the New World's silver was not only being used for Spain's imports, but also trading with Asia. Mauro's article supports it with term of economy of compensation which points Europeans' swap of their commodities among themselves rather than buying. before the discoveries. He asserts that after the discoveries and mercantilist economy, European ports have become centers for intercontinental economy. Increasing money supply in Europe thanks to New World's mines must have been effective for mentioned intercontinental trade because it is stated that Europeans could not have getting the commodities from overseas by their money. Also, influx of bullion to Europe must have relieved an actual or potential monetary constraint on exchange and production, must have eased the trade with Asia and must have led to inflationary conditions in Europe because of accumulation of the capital within the boundaries of the Europe. On the other hand, Braudel's otherwise assumption must be stated, because he refuses the New World's pouring money to deprived Europe and sudden change in the European economy because of these precious metals. He asserts that the contribution of the precious metals to European money supply was not more than 25 percent of the existing money in Europe. Actually, even if the percentage was not clear or was that small, we can clearly state that money supply must have proportionally increased in Europe after precious metals have been used in coinage. Then, whether increasing money supply's effect on Europeans' wealth and dominance in the overseas trade was positive or negative must be questioned. For making it clear, Kristin Plys states that Latin American silver provided Europeans an access to Asian trade and they have flooded the Asian market with silver coin that have caused high-inflationary conditions, social, economic and political problems in everyday life in Asia. By the time, the Asian economy was subjugated to the European economy which would not has been unthinkable a century before. However, with the influx of silver and the subsequent collapse of political power, European colonization of Asia became a real possibility in time, so India and China have really become commercially dependent upon the European world-system. In this manner, Mercantilism can be mentioned as a changing or determinative factor for intercontinental trade and economic center of the world. Actually, this assumption can seem as exaggerated because of being unilateral, so we should add another opinion. Blitz also emphasizes the utmost importance of the Asian trade for European country and he claims that Europe would not be able to trade with Asia because of any reason such as absence of mercantilism which would erase the high inflationary conditions 
in Asia, economic shift would not be happening, because European precious metal would not interfere with Asian economy's dynamics. However, he also asserts that Asians have had chronic problem for all time with monetization of the precious metals. He points out the Keynes's book, Indian currency and Finance, for supporting his argument, claims that the problem of Asians was still going on in 20th century, because Keynes were being able to mentioning the behavior of hoarding, which have dragged the Asian economy, in his book dating to 1913. Blitz himself asserts that in the probable absence of the Asian hoarding, Europeans would experience more inflationary conditions in their countries and could not be benefitting from this trade as much as they could. Thus, it is clear that shifting of economic center and dominance from Asia to Europe was interested in New World's precious metals even if there was another variable that may be effective. European economy that has had capital accumulation through the mercantilism but real expansion for an economy needs to enough population for production. Population growth was also sustained by transplanted species from New World to the Europe.

New species such as sugar, maize, potato and tomato are transplanted from Americas to Europe and new species led to increase in food supply and population. Patrick O'Brien states that from the Americas came a whole range of new crops including maize, potatoes, groundnuts, beans, tobacco, cocoa, pineapples, tomatoes, red peppers, which added variety to the European diet. Only maize and potatoes raised the capacity of agriculture to support population growth. “...the potato helped to stimulate population growth in Ireland, and to feed the working people of England, Belgium, and Germany, the new vegetable was never a critical element in food supplies...". We assert that transplantation of new species has transformed the cultivation in Europe and it clearly led to change in nutrition of European people. As the scholar stated, potato helped to stimulate the population growth in Europe. Potato will be our main focus to understand the population growth in Europe. Why has potato affected profoundly the European diet? How did the potato achieved to make difference among other transplanted plants? Underlying cause of the potato's profound effect on population is biologically nutritive capacity for feeding the people and easy cultivation in large quantities which has eased supplying tons of the potato which needs proportionally less field than other grain and presenting much more calorie than other grain. Nathan Nunn and Nancy Qian mentions "humans can actually subsist healthily on a diet of potatoes, supplemented with only milk or butter, which contain the two vitamins not provided by potatoes, vitamins A and D". Nathan Nunn and Nancy Qian state in their another article "Maize is unable to rival potatoes in terms 
of nutrients or calories. It produces significantly fewer calories per acre of land. Moreover, humans are unable to subsist on a diet that is too concentrated in maize. Significant consumption of maize is associated with pellagra, a disease caused by niacin deficiency". These quotations support clearly our claim about efficiency of the potato and its capacity of calorie. Additionally, in the same article, scholars say "...potatoes accounts for approximately 25-26 percent of the increase in population...", "...single acre of land cultivated with potatoes and one milk cow was nutritionally sufficient for feeding a large family of six to eight...”, "...being relatively easy to store, potatoes provided excellent fodder for livestock, ...a significant proportion of the potato crop would be used as fodder", "The positive productivity shock from the adoption of potatoes can also increase per capita income". We can assert that potatoes were cofactor of the increase in the population and GDP of Europe. There were different species like maize to feed the population, but potatoes were more nutritive and healthy plants. Potato's role in expanding of economy can seem exaggerated but evidence that we get from different sources support our claim. Efficiency of potato in terms of biologically and the ratio of agricultural area to calorie is crystal clear. Its positive effect on population and GDP of the Europe is also evident as we mentioned and supported with different sources. Thereby, increase in population, vital for being emerged market and creating productive economy, completed the other half of current developed economy of Europe.

\section{Conclusion}

Precious metals that have been brought from Americas to Europe have created a huge capital and wealth in the continent as the examples, which we pointed in the first chapter, and Europeans' rising purchasing power thanks to this wealth invaded all the market caused Asian market' downtrend, European's being determinative at the global economy thanks to inflationary pressure over the globe of Europeans' abundant money which is gifted by New World underground sources. Moreover, Population is necessary and indispensable for developed economy as we stated in the second chapter. Need to increase in population is satisfied by potato-like new species that comes from Americas and boosted the European economy. Actually, neither population nor accumulation of capital and money would not be positive on their own. Only boost of population would trigger the decrease in GDP without capital flow from Americas and only capital flow would trigger the hyperinflation that makes a country poverty-stricken. European economy is supported by New World's sources and all conditions are satisfied together to be developed economy thanks to discovery of the New World. 


\section{REFERENCES}

Childs, Wendy R. (1995): "1492-1494: Columbus and the Discovery of America." The Economic History Review, New Series, 48, no. 4 755-66.

Plys, Kristin. (2013): "Eurocentrism and the Origins of Capitalism." Review (Fernand Braudel Center) 36, no. 1 43-77

O'Rourke, Kevin H., and Jeffrey G. Williamson. (2009) "Did Vasco Da Gama Matter for European Markets?" The Economic History Review, New Series, 62, no. 3 656-81.

Phillips, William D. (1992) "Africa and the Atlantic Islands Meet the Garden of Eden: Christopher Columbus's View of America." Journal of World History 3, no. 2 155-63.

Lane, Frederic C. (1950) "Oceanic Expansion: Force and Enterprise in the Creation of Oceanic Commerce." The Journal of Economic History 10 20-30.

Lüthy, Herbert. (1961) "Colonization and the Making of Mankind." The Journal of Economic History 21, no. 4 488-91.

Brading, D. A., and Harry E. Cross. (1972) "Colonial Silver Mining: Mexico and Peru." The Hispanic American Historical Review 52, no. 4 543-76.

Mauro, F. (1961) "Towards an 'Intercontinental Model': European Overseas Expansion between 1500 and 1800." The Economic History Review, New Series, 14, no. 1 1-3.

O'Brien, Patrick. (1982): "European Economic Development: The Contribution of the Periphery." The Economic History Review, New Series, 35, no. 1 4-18.

Blitz, Rudolph C. (1967) "Mercantilist Policies and the Pattern of World Trade, 1500-1750." The Journal of Economic History 27, no.1 39-51.

Nunn, Nathan, and Nancy Qian. (2010) "The Columbian Exchange: A History of Disease, Food, and Ideas." The Journal of Economic Perspectives 24, no. 2: 165-79.

Nunn, Nathan, and Nancy Qian. (2011) "The Potato's Contribution to Population and Urbanization: Evidence from a Historical Experiment." The Quarterly Journal of Economics 126, no. 2 600-658. 